\title{
Skin Tumors among Biopsy Samples in Patients Attending Dermatological OutPatient Departmentin a Tertiary Care Hospital of Nepal: A Descriptive Cross-sectional Study
}

\author{
Shristi Shrestha, ${ }^{1}$ Arnija Rana, ${ }^{1}$ Deepika Karki, ${ }^{2}$ Asim Shrestha ${ }^{2}$ \\ 'Department of Dermatology, Nepal Medical College and Teaching Hospital, Jorpati, Kathmandu, Nepal, ${ }^{2} \mathrm{Nepal}$ \\ Medical College and Teaching Hospital, Jorpati, Kathmandu, Nepal.
}

\begin{abstract}
Introduction: Skin tumors are on the rise in the Nepalese community. The different morphological pattern of skin tumors requires its meticulous categorization for understanding its effect on prognosis and treatment. Our study aimed at studying the prevalence of skin tumors among the skin biopsies performed in the dermatology outpatient department in a tertiary care hospital of Nepal.
\end{abstract}

Methods: A descriptive cross-sectional study was done from skin biopsy samples from $1^{\text {st }}$ January, 2017 to $31^{\text {st }}$ December, 2019, at a tertiary care center. Ethical clearance was taken from the institutional review committee (IRC), Ref No: 056-077/078. Convenience sampling was done. A self-designed proforma containing questions on the patients' socio-demographic data and clinical details were used, and a biopsy of those clinically suspected to have skin tumors was done. Skin tumors were classified according to the World Health Organization 2018 classification of skin tumors. Data were analyzed using Statistical Package for the Social Sciences Version 16. Point estimate at 95\% Confidence Interval was done, and frequency and proportion were calculated.

Results: A total of 671 skin biopsies were done during this study, out of which $125(18.63 \%)$ at 95\% Confidence Interval (15.68-21.57) were diagnosed with skin tumors. Among them, 77 (61.6\%) were female, and 48 (38.4\%) were male. Among the diagnosed cases, $105(84 \%)$ were benign, and $20(16 \%)$ were malignant. Females showed preponderance in both benign and malignant tumors.

Conclusions: The findings from our study show the increasing prevalence of skin tumors, and the results were comparable to other similar studies conducted in various parts of Nepal.

Keywords: benign; malignant; skin neoplasms; tumors.

\section{INTRODUCTION}

Skin tumors result in a proliferation of various components of the skin. They can be benign, simply causing cosmetic concern to premalignant lesions and aggressive tumors. ${ }^{1}$ Benign tumor are circumscribed, have symmetrical architecture, uniform cell nuclei, restraint rate of growth, and absence of metastases. ${ }^{2}$ Malignant tumors are poorly circumscribed, have less symmetrical architecture, atypical cell nuclei, rapid growth, and potential to give rise to metastases. ${ }^{2}$

In Nepal, a study found cutaneous infections and dermatitis to account for the majority of cases. ${ }^{3}$ The indolent 'lumps' and 'bumps' are seen less frequently seeking medical advice. ${ }^{1}$ These tumors have an extensive histo-morphological pattern, and various names are used to denote the same tumors. ${ }^{4}$ So, it is challenging to study their comprehensive types.

Though skin tumors are rare in our population, they opt for investigations to confirm it with the increasing awareness among patients. Our study aimed at studying the

Correspondence: Dr. Deepika Karki, Nepal Medical College and Teaching Hospital, Jorpati, Kathmandu, Nepal. Email: deepika. karki12@gmail.com, Phone: +977-9841836374. 
Shrestha et al. Prevalence of Skin Tumors among Biopsy Samples in Patients attending Dermatological Out Patient Department...

prevalence of skin tumors and their types among the skin biopsies performed in the dermatology outpatient department in a tertiary care hospital of Nepal.

\section{METHODS}

This study was a descriptive cross-sectional study conducted in Nepal Medical College and Teaching Hospital among the patients visiting dermatological OPD from $1^{\text {st }}$ January, 2017 to $31^{\text {st }}$ December, 2019. Ethical clearance was approved from the Institutional Review Committee (IRC) of the college, (Reference number: 056-077/078).

All the patients who were suspected to have skin tumors on the basis of history and clinical examination were asked to get a skin biopsy done and those who consented to get a biopsy done were included in the study. In the first step, a self-designed proforma containing questions on socio-demographic data and clinical details of the patients was administered then depending on the type of lesion punch biopsy, excisional biopsy, incisional biopsy and shave biopsy was done. The histopathological diagnosis was then considered to be the final diagnosis and the confirmed tumor cases were further classified according to World Health Organization (WHO) 2018 classification of skin tumors. ${ }^{5}$

Convenience sampling was done and minimum sample size was calculated as follows:

$$
\begin{aligned}
\mathrm{n} & =Z^{2} \times(\mathrm{p} \times \mathrm{q}) / \mathrm{e}^{2} \\
& =(1.96)^{2} \times(0.197 \times 0.803) /(0.07)^{2} \\
& =124
\end{aligned}
$$

Where,

$\mathrm{n}=$ minimum sample size

$\mathrm{Z}=1.96$ at at $95 \%$ Confidence Interval $(\mathrm{Cl})$

$\mathrm{p}=$ prevalence, $19.7 \%^{8}$

$q=(1-p)$

$\mathrm{e}=$ margin of error, $7 \%$

Selection bias has been minimized as possible and collected data was analyzed using SPSS 16 following which descriptive analysis was done. Point estimate at $95 \%$ Confidence Interval was done for binary data along with analysis for frequency and proportion.

\section{RESULTS}

A total of 671 skin biopsies were done during this period and 125 were confirmed to be skin tumors on histopathological examination, the frequency being
$18.63 \%$ out of the total biopsied sample. Out of 125 patients, 20 (16\%) had malignant tumors, whereas 105 $(84 \%)$ had benign tumors.

When the skin tumors were classified according to WHO 2018 classification, majority were keratinocytic $44(35.2 \%)$, followed by soft tissue tumors 39 $(31.2 \%)$, melanocytic tumors $21(16.8 \%)$, appendageal tumors 12 (9.6\%) and neural tumors 9 (7.2\%). Among benign tumors, the majority were soft tissue tumors 39 (37.1\%) followed by keratinocytic tumors $26(24.7 \%)$, melanocytic $20(19.1 \%)$, appendageal 11 (10.5\%) and neural tumors 9 (8.6\%). Whereas, among malignant tumors, keratinocytic tumors were the commonest in 18 out of 20 (90\%). Appendageal tumors and melanoma

\begin{tabular}{|c|c|c|c|}
\hline $\begin{array}{l}\text { Group of } \\
\text { neoplasm }\end{array}$ & $\begin{array}{l}\text { Benign } \\
\text { tumor } \\
\mathrm{n}(\%)\end{array}$ & $\begin{array}{l}\text { Malignant } \\
\text { tumor } \\
\mathrm{n}(\%)\end{array}$ & $\begin{array}{l}\text { Total } \\
\text { n (\%) }\end{array}$ \\
\hline $\begin{array}{l}\text { Keratinocytic } \\
\text { tumor }\end{array}$ & $26(20.8)$ & $18(14.4)$ & $44(35.2)$ \\
\hline $\begin{array}{l}\text { Appendageal } \\
\text { tumor }\end{array}$ & $11(8.8)$ & $1(0.8)$ & 12 (9.6) \\
\hline $\begin{array}{l}\text { Melanocytic } \\
\text { tumor }\end{array}$ & $20(16.0)$ & $1(0.8)$ & $21(16.8)$ \\
\hline $\begin{array}{l}\text { Soft tissue } \\
\text { tumor }\end{array}$ & 39 (31.2) & $0(0.0)$ & 39 (31.2) \\
\hline Neural tumor & $9(7.2)$ & $0(0.0)$ & $9(7.2)$ \\
\hline Total & $105(84.0)$ & $20(16.0)$ & $125(100)$ \\
\hline
\end{tabular}
were seen in 1 patient each. Malignancy of soft tissue was not seen at all (Table 1).

The age group of patients ranged from 45 days to 90 years of age and the maximum number of patients were in the age group of 31-40 years.

Benign tumors were observed more in the age group of 31-40 years. Benign soft tissue tumors were observed mostly in the age group of $31-40$ years, whereas keratinocytic benign tumors were more frequent in 5160 years of age. Malignant tumors were observed more frequently in the older age groups of 51-60 years and 71-80 years (Table 2). Females showed preponderance in both benign and malignant skin tumors (Table 3 ). 
Shrestha et al. Prevalence of Skin Tumors among Biopsy Samples in Patients attending Dermatological Out Patient Department...

\begin{tabular}{|c|c|c|c|c|c|c|c|c|c|c|c|}
\hline & \multicolumn{2}{|c|}{$\begin{array}{l}\text { Keratinocytic } \\
\text { tumors }\end{array}$} & \multicolumn{2}{|c|}{$\begin{array}{l}\text { Appendageal } \\
\text { tumors }\end{array}$} & \multicolumn{2}{|c|}{$\begin{array}{l}\text { Melanocytic Mel- } \\
\text { anoma }\end{array}$} & \multicolumn{2}{|c|}{ Soft tissue tumors } & \multicolumn{2}{|c|}{ Neural tumors } & \multirow[t]{2}{*}{$\begin{array}{l}\text { Total } n \\
(\%)\end{array}$} \\
\hline & $\begin{array}{l}\text { Benign } \\
\text { n (\%) }\end{array}$ & $\begin{array}{l}\text { Malig- } \\
\text { nant } n \\
(\%)\end{array}$ & $\begin{array}{l}\text { Benign } \\
\mathrm{n}(\%)\end{array}$ & $\begin{array}{l}\text { Malig- } \\
\text { nant n } \\
(\%)\end{array}$ & $\begin{array}{l}\text { Benign } \\
\text { n (\%) }\end{array}$ & $\begin{array}{l}\text { Malig- } \\
\text { nant n } \\
(\%)\end{array}$ & $\begin{array}{l}\text { Benign } \\
\text { n (\%) }\end{array}$ & $\begin{array}{l}\text { Malig- } \\
\text { nant n } \\
(\%)\end{array}$ & $\begin{array}{l}\text { Benign } \\
\text { n (\%) }\end{array}$ & $\begin{array}{l}\text { Malig- } \\
\text { nant } n \\
(\%)\end{array}$ & \\
\hline $\begin{array}{l}0- \\
10 y r s\end{array}$ & 0 & 0 & 0 & 0 & 0 & 0 & $3(7.69)$ & 0 & 0 & 0 & $3(2.4)$ \\
\hline $\begin{array}{l}11- \\
20 y r s\end{array}$ & $\begin{array}{l}2 \\
(7.69)\end{array}$ & 0 & $3(20)$ & 0 & $4(20)$ & 0 & $\begin{array}{l}5 \\
(12.82)\end{array}$ & 0 & $\begin{array}{l}1 \\
(11.11)\end{array}$ & 0 & $15(12 \%)$ \\
\hline $\begin{array}{l}21- \\
30 y r s\end{array}$ & $\begin{array}{l}1 \\
(3.84)\end{array}$ & 0 & $2(10)$ & 0 & $5(25)$ & 0 & $\begin{array}{l}10 \\
(25.64)\end{array}$ & 0 & $\begin{array}{l}2 \\
(22.22)\end{array}$ & 0 & $20(16)$ \\
\hline $\begin{array}{l}31- \\
40 y s\end{array}$ & $\begin{array}{l}5 \\
(19.23)\end{array}$ & $1(5.55)$ & $4(13)$ & 0 & $6(30)$ & 0 & $\begin{array}{l}12 \\
(30.77)\end{array}$ & 0 & $\begin{array}{l}3 \\
(33.33)\end{array}$ & 0 & $31(24.8)$ \\
\hline $\begin{array}{l}41- \\
50 y r s\end{array}$ & $\begin{array}{l}5 \\
(19.23)\end{array}$ & $\begin{array}{l}2 \\
(11.11)\end{array}$ & 0 & 0 & $2(10)$ & 0 & 0 & 0 & $\begin{array}{l}2 \\
(22.22)\end{array}$ & 0 & $11(8.8)$ \\
\hline $\begin{array}{l}51- \\
60 y r s\end{array}$ & $\begin{array}{l}8 \\
(30.77)\end{array}$ & $\begin{array}{l}4 \\
(22.22)\end{array}$ & 0 & $\begin{array}{l}1 \\
(100)\end{array}$ & $2(10)$ & $1(100)$ & $\begin{array}{l}6 \\
(15.38)\end{array}$ & 0 & 0 & 0 & $22(17.6)$ \\
\hline $\begin{array}{l}61- \\
70 y r s\end{array}$ & $\begin{array}{l}3 \\
(11.54)\end{array}$ & $\begin{array}{l}4 \\
(22.22)\end{array}$ & $\begin{array}{l}1 \\
(8.33)\end{array}$ & 0 & $1(5)$ & 0 & $3(7.69)$ & 0 & 0 & 0 & $12(9.6)$ \\
\hline $\begin{array}{l}71- \\
80 y r s\end{array}$ & $\begin{array}{l}1 \\
(3.84)\end{array}$ & $\begin{array}{l}6 \\
(33.33)\end{array}$ & $\begin{array}{l}1 \\
(11.11)\end{array}$ & 0 & 0 & 0 & 0 & 0 & $\begin{array}{l}1 \\
(11.11)\end{array}$ & 0 & $9(7.2)$ \\
\hline $\begin{array}{l}81- \\
90 y r s\end{array}$ & $\begin{array}{l}1 \\
(3.84)\end{array}$ & $1(5.55)$ & 0 & 0 & 0 & 0 & 0 & 0 & 0 & 0 & $2(1.6)$ \\
\hline Total & $\begin{array}{l}26 \\
(100)\end{array}$ & $18(100)$ & $\begin{array}{l}11 \\
(100) \\
\end{array}$ & $\begin{array}{l}1 \\
(100)\end{array}$ & $\begin{array}{l}20 \\
(100)\end{array}$ & $1(100)$ & $\begin{array}{l}39 \\
(100)\end{array}$ & 0 & $9(100)$ & 0 & $\begin{array}{l}125 \\
(100)\end{array}$ \\
\hline
\end{tabular}

\begin{tabular}{|llll|}
\hline \multicolumn{4}{|l|}{$\begin{array}{l}\text { Table } \\
\text { malignant tumors. }\end{array}$} \\
\hline Sex & Benign & Malignant & Total $\mathbf{n}(\%)$ \\
& $\begin{array}{l}\text { Number of } \\
\text { patients } \mathbf{n}(\%)\end{array}$ & $\begin{array}{l}\text { Number of } \\
\text { patients } \mathbf{n}(\%)\end{array}$ \\
Female & $61(58.1)$ & $16(80)$ & $77(61.6)$ \\
Male & $44(41.9)$ & $4(20)$ & $48(38.4)$ \\
Total & $105(100)$ & $20(100)$ & $125(100)$ \\
\hline
\end{tabular}

The commonest site involved was the head, neck and face region in $60(48 \%)$ patients. Other sites of involvement were trunk 31 (24.8\%), upper limb 17 $(13.6 \%)$, lower limb $14(11.2 \%)$ and external genitalia $3(2.4 \%)$.

Among the 12 appendageal tumors, benign tumors were 11 in number and only one was malignant tumor which was extra mammary Paget's disease. Among benign appendageal tumors, the commonest was tumor with follicular differentiation in 8 (72.7 $\%)$ followed by tumors with eccrine and apocrine differentiation in $3(27.3 \%)$ (Table 4$)$.

\begin{tabular}{|l}
\hline \begin{tabular}{llll|}
\hline Table 4. Distribution of skin appendageal tumors \\
according to WHO classification & 2018. \\
\hline Appendageal Tumors & Benign & Malignant & Total \\
& $\mathbf{n}(\%)$ & $\mathbf{n}(\%)$ & $\mathbf{n}(\%)$ \\
$\begin{array}{l}\text { Tumor with Follicular } \\
\text { differentiation }\end{array}$ & $8(72.7)$ & $0(0.0)$ & $8(66.7)$
\end{tabular}
\end{tabular}

\begin{tabular}{llll|}
$\begin{array}{l}\text { Tumor with eccrine } \\
\text { and Apocrine }\end{array}$ & $3(27.3)$ & $0(0.0)$ & $3(25)$ \\
differentiation & & & \\
$\begin{array}{l}\text { Site specific tumor: } \\
\text { Extramammary Paget } \\
\text { disease }\end{array}$ & & $1(100)$ & $1(8.3)$ \\
Total & $11(100)$ & $1(100)$ & $12(100)$ \\
\hline
\end{tabular}

Out of 105 benign tumors, seborrheic keratosis was the most frequently observed in 20 (19\%) followed by intradermal nevus in 14 (13.3\%). Other frequently encountered benign tumors were dermatofibromas in $11(10.4 \%)$ and lobular capillary hemangiomas in 11 $(10.4 \%)$ followed by neurofibromas in 8 (7.6\%) (Table $5)$. Among malignant keratinocytic tumors, Basal cell carcinoma (BCC) was the commonest in 55\% (11 out of 20), followed by Squamous cell carcinoma (SCC) in

$25 \% \quad(5$ out of 20) (Table 5).

\begin{tabular}{|c|c|c|}
\hline \multirow[t]{2}{*}{ S.N } & Variables & n (\%) \\
\hline & Benign Tumors & $\begin{array}{l}\text { Number of } \\
\text { patients } n(\%)\end{array}$ \\
\hline \multirow[t]{5}{*}{1} & Benign Keratinocytic $t$ & \\
\hline & Squamous papilloma & $2(1.9)$ \\
\hline & Seborrheic keratosis & $20(19.0)$ \\
\hline & Stucco keratosis & $1(0.9)$ \\
\hline & Verruca vulgaris & $3(2.9)$ \\
\hline 2 & Appendageal tumors & \\
\hline
\end{tabular}


Shrestha et al. Prevalence of Skin Tumors among Biopsy Samples in Patients attending Dermatological Out Patient Department...

\begin{tabular}{|c|c|c|}
\hline & Follicular differentiation & \\
\hline & Trichoblastoma & $3(2.9)$ \\
\hline & Pilomatricoma & $3(2.9)$ \\
\hline & Trichofolliculoma & $2(1.9)$ \\
\hline & $\begin{array}{l}\text { Eccrine and Apocrine } \\
\text { differentiation }\end{array}$ & \\
\hline & Syringoma & $1(0.9)$ \\
\hline & Spiradenoma & $1(0.9)$ \\
\hline & $\begin{array}{l}\text { Syringocystadenoma } \\
\text { papilliferum }\end{array}$ & $1(0.9)$ \\
\hline 4 & Melanocytic tumors & \\
\hline & $\begin{array}{l}\text { Lentiginous junctional } \\
\text { melanocytic nevus }\end{array}$ & $1(0.9)$ \\
\hline & Junctional nevus & $1(0.9)$ \\
\hline & Compound nevus & $3(2.9)$ \\
\hline & Intradermal naevus & $14(13.3)$ \\
\hline & Pigmented spindle cell nevus & $1(0.9)$ \\
\hline 5 & Soft tissue tumors & \\
\hline & Adipocytic tumors & \\
\hline & Lipoma & $5(4.7)$ \\
\hline & Angiolipoma & $1(0.9)$ \\
\hline & $\begin{array}{l}\text { Fibroblastic and } \\
\text { fibrohistiocytic tumors }\end{array}$ & \\
\hline & Dermatofibroma & $11(10.4)$ \\
\hline & Fibromas & $3(2.9)$ \\
\hline & Cutaneous myxoma & $1(0.9)$ \\
\hline & Smooth muscle tumors & \\
\hline & Cutaneous leiomyoma & $2(1.9)$ \\
\hline & (Myo)pericytic tumors & \\
\hline & Glomus tumor & $1(0.9)$ \\
\hline 6 & Vascular tumors & \\
\hline & Hemangiomas & \\
\hline & Epithelioid hemangioma & $1(0.9)$ \\
\hline & Angiokeratoma & $2(1.9)$ \\
\hline & Infantile hemangioma & $1(0.9)$ \\
\hline & $\begin{array}{l}\text { Lobular capillary } \\
\text { hemangioma }\end{array}$ & $11(10.4)$ \\
\hline & Neural tumors & \\
\hline & Neurofibroma & $8(7.6)$ \\
\hline & Schwannoma & $1(0.9)$ \\
\hline & Total & $105(100)$ \\
\hline & Malignant tumors & \\
\hline 1 & Keratinocytic tumors & \\
\hline & Basal cell carcinoma & $11(55.0)$ \\
\hline & Squamous cell carcinoma & $7(35.0)$ \\
\hline 2 & Appendageal tumors & \\
\hline & $\begin{array}{l}\text { Site-specific tumor } \\
\text { Extramammary Paget } \\
\text { disease }\end{array}$ & $1(5.0)$ \\
\hline 3 & $\begin{array}{l}\text { Melanocytic tumor } \\
\text { Desmoplastic melanoma }\end{array}$ & $1(5.0)$ \\
\hline & Total & $20(100)$ \\
\hline
\end{tabular}

Both of these malignancies were more frequently observed among females with basal cell carcinoma in $9(45 \%)$ females; squamous cell carcinoma in 6 $(30 \%)$; extramammary Paget disease in $1(5 \%)$; and desmoplastic melanoma in $1(5 \%)$ females.

\section{DISCUSSION}

The incidence of skin cancer is increasing globally. ${ }^{6}$ Various studies from Nepal has also shown an increasing trend in skin cancers. ${ }^{7-8}$ Skin biopsy is a simple and inexpensive procedure, which identifies the architectural pattern of tumor and growth of infiltration to distinguish the malignant tumour. ${ }^{9-10}$ It is important to diagnose the malignant skin tumors due to its therapeutic implications and aggressive nature. ${ }^{1,9}$ Management of benign tumors are usually done for cosmetic reasons. ${ }^{1}$

Various studies have shown that benign tumors are common in younger age groups whereas malignant tumors are mostly seen in older age groups. ${ }^{9-19} \mathrm{~A}$ similar pattern was noted in our study with maximum number of benign neoplasms in 31-40 years and malignant tumors in 51-60 years and 71-80 years. Genetic susceptibility, environmental factors, mainly chronic exposure to ultraviolet (UV) radiation, ionizing radiation, and chemical carcinogens such as arsenic exposure are some of the risk factors for non- melanoma skin carcinoma. ${ }^{20-24}$

Our study showed a female preponderance among both the benign and malignant tumors. Females also had more benign tumors in various other studies from Nepal. ${ }^{10-12}$ Similar to our study malignant skin tumors were commoner in females in a study by Adhikari et al. ${ }^{19}$ This may be due to the fact that females have health seeking behavior for their skin problems as they are more cosmetically concerned compared to males.

In our study, maximum number of skin tumors, both benign and malignant were seen in the head, face and neck region which is comparable with the studies from Karki et al, Shrivastava et al and Narhire et al. ${ }^{10,13-14}$ Head, face and neck are the sun exposed areas and of cosmetic concern to the patients, which might explain the high frequency of tumors.

Majority of skin tumors are benign in nature. ${ }^{1}$ Similarly, in our study as well out of 125 skin tumors, $84 \%$ were benign and $16 \%$ were malignant. In the study done by Sherpa and $\mathrm{KC}^{11}$, out of 214 skin tumors, $81.8 \%$ were benign and $18.2 \%$ were malignant. ${ }^{11}$ Similar results were obtained from various studies from Nepal. ${ }^{10,12}$ Studies from India also showed higher number of benign tumors. ${ }^{9,13-14}$

In our study, the majority of skin tumors were keratinocytic $35.2 \%$, followed by soft tissue tumors $31.2 \%$, melanocytic tumors $16.8 \%$ and appendageal 
Shrestha et al. Prevalence of Skin Tumors among Biopsy Samples in Patients attending Dermatological Out Patient Department...

tumors 9.6\%. Keratinocytic tumors have been observed to be the commonest skin tumors in Nepal in studies done by Sherpa and KC and Thapa et al also. ${ }^{11-}$ ${ }^{12}$ Maximum number of malignant tumors in our study belonged to the keratinocytic category by $90 \%$. Similar findings were observed in various studies. ${ }^{10,11-12}$

In our study, out of 105 benign tumors, soft tissue tumors of dermis (37.1\%) were commonest followed by keratinocytic tumors. Karki et al also showed out of 142 cases of benign tumors, soft tissue tumors of the dermis $(34 \%)$ were commonest followed by keratinocytic tumors. ${ }^{10}$ Some studies found appendageal tumors to be more frequent among the benign skin tumors. ${ }^{13,15}$

Out of 20 malignant tumors in the study, BCC was the commonest in 11 cases (55\%) followed by SCC which were in 5 cases (25\%). Similar results of higher frequency of BCC have been reported in studies done in Nepal as well as other countries. ${ }^{7,16-19}$ But some other studies have shown SCC as the commonest malignant skin tumor. ${ }^{9-15}$

Malignant melanoma was found to be the least common malignant tumor constituting only a single case in this study. Similar results of less frequency of melanoma were seen in various other studies from Asia. ${ }^{11-13,16-18}$ This is in contrast to the higher frequencies of melanoma from Australia and European countries. ${ }^{25,-27}$

In the present study, among the benign tumors, seborrheic keratosis was the most common $19.0 \%$, followed by intradermal nevus 13.3\%. Seborrheic keratosis was the second most common in the study by Thapa et al. ${ }^{12}$

Appendageal tumors comprised $9.6 \%$ of total cases, out of which benign appendageal tumors $10.5 \%$ were more common than malignant $5 \%$. Karki et al, also showed similar results of higher frequency of benign appendageal tumors compared to malignant. ${ }^{10}$ Tumors with follicular differentiation $72.7 \%$ were frequently encountered among the benign appendageal tumors. This was followed by tumors with eccrine apocrine differentiation in $37.3 \%$. In our study, pilomatricoma, $2.9 \%$ and trichoblastoma, $2.9 \%$ were the commonest among follicularbenigntumors. Pilomatricoma wasalso the commonest appendageal tumors in various other studies. ${ }^{11-14}$

In our study, among the benign soft tissue tumors, lobular capillary hemangiomas and dermatofibromas were frequently observed. Lobular capillary hemangiomas were also the most frequently seen benign soft tissue tumor in the study done by Sherpa and KC. ${ }^{11}$

Less number of the cases for the extensive variety of benign and malignant tumors is the limitation of this study. In the future, a similar study on a large number of cases from multiple centers following a uniform classification system could help find out the true incidence of skin tumors.

\section{CONCLUSIONS}

Worldwide, a large number of studies have been reported pointing towards the increasing incidence of skin tumors and a similar trend is being seen in Nepal as evident from the multiple literature available in the matter.

The skin tumors have a wide and extensive categorical differentiation based on WHO and are thus required to be meticulously evaluated for understanding the pattern of distribution of the specific tumor type in different sexes and various age groups.

Our study concluded that the prevalence of skin tumors is increasing and the condition is seen more commonly in females. Benign skin tumors are commoner in young age groups whereas malignant skin tumors are more seen in elderly. This indicates the requirement of more screening facilities and extensive dissemination of information regarding the indolent lumps and bumps of the skin that are most often under looked by the patients. This can lead to early help seeking behavior and subsequently early detection and treatment for the condition.

\section{ACKNOWLEDGEMENTS}

We would like to extend our sincere gratitude to the Department of Dermatology and Department of Pathology, Nepal Medical College for their support.

\section{Conflict of Interest: None.}

\section{REFERENCES}

1. Khandpur S, Ramam M. Skin tumours. J Cutan Aesthet Surg. 2012 Jul;5(3):159-62. [uued | Full Text | DOI]

2. Kirkham N, Aljefri K. Tumors and cysts of the epidermis. In: Elder DE, Walter Lever, editors. Lever's histopathology of the skin. 11th ed. Philadelphia: Wolters Kluwer; 2015; p 969. [Full Text]
3. Basnet B, Neupane S, Shrestha S, Gautam S. Burden of Skin Diseases in Western Nepal: A Hospital Based Study. American Journal of Public Health Research. Vol. 3, No. 5A, 2015, pp 64-66. [Full Text]

4. Billings SD. Tumors and tumor like Condition of the Skin. Rosai and Ackerman's Surgical Pathology 11th ed, Vol. 2. 
Shrestha et al. Prevalence of Skin Tumors among Biopsy Samples in Patients attending Dermatological Out Patient Department...

Edinburg: St. Louis, Missouri Mosby;2017;p45. [Full Text]

5. Elder DE, Massi D, Scolyer RA, Willemze R. WHO Classification of Skin Tumours. 4th edn. Lyon, France: International Agency for Research on Cancer; 2018. [Full Text]

6. Leiter U, Eigentler T, Garbe C. Epidemiology of skin cancer. Adv Exp Med Biol. 2014;810:120-40. [라Med | Full Text | DOI]

7. Kumar A, Shrestha PR, Pun J, Thapa P, Manandhar M, Sathian B. Profile of skin biopsies and patterns of skin cancer in a tertiary care center of Western Nepal. Asian Pac J Cancer Prev. 2015;16(8):3403-6. [라bMed | Full Text | DOI]

8. Adhikari RC, Shah M, Jha AK. Histopathological spectrum of skin diseases in a tertiary skin health and referral centre. Journal of Pathology of Nepal 2019;9:1434-40. [․ㅏll Text | DOI]

9. Samanta M, Mangal N, Bhavani K, Koteeswaran G, Parmar P.C. Histopathological study of skin tumours. Trop J Path Micro 2018;4(2):195-200. [Full Text]

10. Karki D, Jha A, Shreevastav S, Pokhrel DB. Histopathological evaluation of tumours and tumour like lesions of skin and adnexa. J Pathol Nep 2018;8:1353-9. [Full Text | DOI]

11. Sherpa P, KC Shiva R. Histopathological evaluation of skin neoplasms. Nep Med J 2018;1:89- 93. [Full Text | DOI]

12. Thapa R, Gurung P, Hirachand S, Shrestha SB. Histomorphologic Profile of Skin Tumors. JNMA J Nepal Med Assoc. 2018 Nov-Dec;56(214):953-7. [마bMed | Full Text $\mid \underline{\mathrm{DOI}}]$

13. Shrivastava V, Tangde A, Joshi A, Bindu R. Clinicopathological study of skin tumours. Int J Res Med Sci 2019;7:1712-9. [Full Text | DOI]

14. Narhire VV, Swami SY, Baste BD, Khadase SA, D'costa GF. A Clinicopathological study of skin and adnexal neoplasms at a rural based tertiary teaching hospital. Asian Pac. J. Health Sci. 2016;3(2):153-62. [Full Text]

15. Nandyal S, and R Puranik. Study of demographic profile of skin tumors in a tertiary care hospital. IJCRR. 2014;6(16): 24-28. [Full Text]

16. Albasri AM, Borhan WM. Histopathological pattern of skin cancer in Western region of Saudi Arabia. An 11 years experience. Saudi Med J. 2018 Oct;39(10):994-8.[PubMed | Full Text | DOI]

17. Tan SH, Tham SN, Goh CL. Skin cancers at Tertiary Referral Skin Hospital in Singapore. Int J Dermatol. 1995 Nov;34(11):770-6.[PubMed | Full Text | DOI]
18. Rezende HD, Almeida APM, Shimoda E, Milagre ACX, Almeida LM. Study of skin neoplasms in a university hospital: integration of anatomopathological records and its interface with the literature. An Bras Dermatol. 2019 Jan-Feb;94(1):42-6. [PubMed | Full Text | DOI]

19. Adhikari RC, Shah M, Jha AK. Histopathological pattern of skin cancer at tertiary referral skin health centre. J Pathol Nep 2019; 9:1555-9. [Full Text]

20. Vitasa BC, Taylor HR, Strickland PT, Rosenthal FS, West S, Abbey H, Ng SK, Munoz B, Emmett EA. Association of nonmelanoma skin cancer and actinic keratosis with cumulative solar ultraviolet exposure in Maryland watermen. Cancer. 1990 Jun 15;65(12):2811-7. [PubMed |

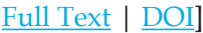

21. Stern RS, Liebman EJ, Väkevä L. Oral psoralen and ultraviolet-A light (PUVA) treatment of psoriasis and persistent risk of nonmelanoma skin cancer. PUVA Follow-up Study. J Natl Cancer Inst. 1998 Sep 2;90(17):1278-84. [PubMed | Full Text | DOI]

22. Pfeifer GP, Besaratinia A. UV wavelength-dependent DNA damage and human non-melanoma and melanoma skin cancer. Photochem Photobiol Sci. 2012 Jan;11(1):90-7. [PubMed | Full Text | DOI]

23. Beani JC. Ultraviolets A et dommages de l'ADN ;leur place dans la cancérogenèsecutanée [Ultraviolet A-induced DNA damage: role in skin cancer]. Bull Acad Natl Med. 2014 Feb;198(2):273-95. French. [PubMed]

24. Que SKT, Zwald FO, Schmults CD. Cutaneous squamous cell carcinoma: Incidence, risk factors, diagnosis, and staging. J Am Acad Dermatol. 2018 Feb;78(2):237-247. [․ㅏbMed | Full $\underline{\text { Text }}$ | $\underline{\mathrm{DOI}}]$

25. Rastrelli M, Tropea S, Rossi CR, Alaibac M. Melanoma: epidemiology, risk factors, pathogenesis, diagnosis and classification. In Vivo. 2014 Nov-Dec;28(6):1005-11. [

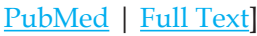

26. Watts CG, Madronio C, Morton RL, Goumas C, Armstrong BK, Curtin A, Menzies SW, Mann GJ, Thompson JF, Cust AE. Clinical Features Associated With Individuals at Higher Risk of Melanoma: A Population-Based Study. JAMA Dermatol. 2017 Jan 1;153(1):23-29. [ubMed | Full Text | DOI]

27. de Vries E, Bray FI, Coebergh JW, Parkin DM. Changing epidemiology of malignant cutaneous melanoma in Europe 1953-1997: rising trends in incidence and mortality but recent stabilizations in western Europe and decreases in Scandinavia. Int J Cancer. 2003 Oct 20;107(1):119-26. [PubMed | Full Text | DOI]

This work is licensed under a Creative Commons Attribution 4.0 International License. The images or other third party material in this article are included in the article's Creative Commons license, unless indicated otherwise in the credit line; if the material is not included under the Creative Commons license, users will need to obtain permission from the license holder to reproduce the material. To view a copy of this license, visit http://creativecommons.org/licenses/by/4.0/ 